\title{
Inheritance of Mungbean Yellow Mosaic Virus Disease Resistance in Greengram [Vigna radiata (L.) Wilczek]
}

\author{
A. Mahalingam*, V.K. Satya, N. Manivannan, S. Lakshmi Narayanan and P. Sathya \\ National Pulses Research Centre, Tamil Nadu Agricultural University, Vamban, \\ Pudukkottai - 622 303, Tamil Nadu, India \\ *Corresponding author
}

\begin{abstract}
A B S T R A C T
Keywords

Greengram,

Mungbean yellow

mosaic virus,

Inheritance

Article Info

Accepted:

10 December 2017

Available Online:

10 January 2018

Mungbean Yellow Mosaic Virus (MYMV) disease is one of the most devastating diseases of greengram causing $85-100$ per cent yield loss and transmitted by the white fly, Bemisia tabaci. This has become increasingly serious because of the lack of resistance in the existing cultivars. Ten greengram genotypes were screened for MYMV disease resistance at hotspot of National Pulses Research Centre, Vamban during kharif season. Among them, SML 1815, MH 421 showed resistant reaction whereas, VBN (Gg) 3, VBN (Gg) 2, LGG 460, RMG 10-28 and TM 96-2 showed susceptible reaction. Three crosses were made between resistant and susceptible genotypes. The three $\mathrm{F}_{2}$ populations were sown along with blackgram CO5 as infector row for evaluation against MYMV resistance. The $F_{2}$ population segregated in the ratio of 15R:1S and 13R:3S, suggesting the involvement of two dominant genes in imparting resistance against MYMV disease.
\end{abstract}

\section{Introduction}

Yellow Mosaic Virus Disease (YMVD) inflicts heavy yield losses in five economically important food legumes including blackgram (Vigna mungo), soybean (Glycine max), mungbean (Vigna radiata), frenchbean (Phaseolus vulgaris) and mothbean (Vigna aconitifolia). Greengram, which is mainly cultivated in India, Myanmar, Thialand, Philippines and Pakistan are highly prone to YMVD. The disease is caused by representative species of the genus Begomovirus. Based on several studies, it has been confirmed that at least two virus species causing YMVD are prevalent in Indian subcontinent. One of these species, mungbean yellow mosaic India virus (MYMIV) is commonly occurring in northern part of Indian sub-continent while Mungbean Yellow Mosaic Virus (MYMV) is mostly confined to peninsular region of India (Varma and Malathi, 2003; Malathi and John, 2008). These two virus species can easily be distinguished on the basis of nucleotide sequence identity (Fauquet et al., 2003).

The losses due to Mungbean Yellow Mosaic Virus Disease (MYMVD) have been observed from 60 to $100 \%$. Since the virus 
transmission is attributed by the vectorwhitefly (Bemisia tabaci), control of MYMVD based upon limiting the vector population by using insecticides is ineffective under severe whitefly infestations. Further, this is also not an eco-friendly approach. The most effective way to prevent the occurrence of this disease is to develop genetically resistant cultivars of greengram. There are conflicting reports about the genetics of resistance to MYMVD, claiming both resistance and susceptibility to be dominant. Monogenic dominant nature of resistance was reported by Dahiya et al., (1977), Kaushal and Singh (1988) and Gupta et al., (2005) while it was reported to be digenic recessive by Singh (1980), Dwivedi and Singh (1985), Verma and Singh (1986). Monogenic recessive control of yellow mosaic resistance has also been reported (Pal et al., 1991; Reddy and Singh, 1995).

Information on the inheritance of resistance to MYMVD disease is useful in breeding for resistant cultivars. Inheritance of resistance to MYMVD in mungbean has been studied extensively using different resistant sources but results were contradictory. Therefore the present investigation was conducted to understand the inheritance pattern of resistance to MYMVD in the segregating material as mentioned below.

\section{Materials and Methods}

The present investigation was conducted at National Pulses Research Center, Vamban a hot spot for MYMVD screening in India. A total of ten mungbean genotypes (Table 1) were screened for their resistance against MYMVD during Kharif 2015. Based on the screening results two resistant genotypes viz., SML 1815 and MH 421 and two susceptible genotypes viz., VBN (Gg) 2 and VBN (Gg) 3 (Table 2) were used to produce three cross combinations viz., VBN(Gg) 2 x SML 1815,
VBN(Gg) 3 x SML 1815, VBN (Gg) 3 x MH 421 during Kharif 2015. These $\mathrm{F}_{1} \mathrm{~s}$ were raised along with parents during rabi 2015-16 and true $F_{1}$ plants were identified to build up $F_{2}$ population. All the three $\mathrm{F}_{2}$ populations were evaluated during kharif 2016 along with highly susceptible cultivar CO 5 of blackgram (Vigna mungo (L.) Hepper) as infector row. For each four rows of $F_{2}$ populations, an infector row of $\mathrm{CO} 5$ was raised to intensify the MYMVD pressure. Insecticides were not sprayed during the cropping period in order to maintain the natural whitefly population in the field. Individual plants of the parents and $F_{2}$ were scored after 100 per cent of the plants in infector rows showed MYMV disease.

Based upon the MYMVD score, the mungbean plants were classified into five categories, resistant $(\mathrm{R})$, moderately resistant (MR), moderately susceptible (MS), susceptible (S) and highly susceptible (HS). Plants that are moderately susceptible (MS), susceptible (S) and highly susceptible (HS) were included in susceptible group while the resistant (R), moderately resistant (MR) were included in resistant group. Mendelian segregation ratio for MYMVD (resistance: susceptible) in the segregating population was tested through Chi-square test to confirm goodness of fit of each cross.

\section{Results and Discussion}

In India, the major bottleneck experienced in the expansion of mungbean cultivation has been attributed to its susceptibility to mungbean yellow mosaic virus which is most threatening disease of mungbean. Cultivation of resistant varieties is the cheapest and most effective method of combating mungbean yellow mosaic virus. For developing high yielding, yellow mosaic virus resistant varieties, it is prerequisite to identify the stable resistant source as well as to understand its nature of inheritance. 
Ten mungbean genotypes, namely SML 1815, resistance reaction to mungbean yellow MH 421, IPM 409-4, IPM 410-3, LGG 460, RMG 10-28, TM 96-2, Gam 5, VBN (Gg)2 and VBN (Gg)3 were screened for their resistance against MYMVD during kharif 2015 season. Among these genotypes, LGG 460, TM 96-2, RMG 10-28, VBN (Gg)2 and VBN(Gg) 3 clearly exhibited susceptibility whereas SML 1815 and MH 421 showed

mosaic virus (MYMV) (Table 1).

To decipher the inheritance pattern of MYMV resistance, three greengram cross combinations were effected viz., $\mathrm{VBN}(\mathrm{Gg}) 2 \mathrm{x}$ SML 1815, VBN(Gg) 3 x SML 1815, VBN (Gg) $3 \times \mathrm{MH} 421$ and evaluated during rabi 2015-16 season (Table 2).

The rating scale suggested by Singh et al., (1988), was adopted as given below

\begin{tabular}{|c|c|c|}
\hline Scale & Percentage of plant foliage affected & Reaction \\
\hline 1 & $\begin{array}{l}\text { Mottling of leaves covering } 0.1 \text { to } 5.0 \% \text { of the leaf } \\
\text { area }\end{array}$ & Resistant \\
\hline 3 & $\begin{array}{l}\text { Mottling of leaves covering } 5.1 \text { to } 10.0 \% \text { of the leaf } \\
\text { area }\end{array}$ & Moderately resistant \\
\hline 5 & $\begin{array}{l}\text { Mottling and yellow discolouration of } 10.1 \\
\text { to } 25.0 \% \text { of the leaf area }\end{array}$ & Moderately susceptible \\
\hline 7 & $\begin{array}{l}\text { Mottling and yellow discolouration of } 25.1 \text { to } 50.0 \% \\
\text { of the leaf area }\end{array}$ & Susceptible \\
\hline 9 & $\begin{array}{l}\text { Severe yellow mottling on more than } 50.0 \% \\
\text { and up to } 100 \% \text { of the leaf area }\end{array}$ & Highly Susceptible \\
\hline
\end{tabular}

Table.1 Details of the mungbean genotypes and their reaction against MYMV disease

\begin{tabular}{|c|l|c|c|l|}
\hline Sl. No & \multicolumn{1}{|c|}{$\begin{array}{c}\text { Variety / } \\
\text { Genotype }\end{array}$} & $\begin{array}{c}\text { Total No. of plants } \\
\text { screened }\end{array}$ & $\begin{array}{c}\text { Disease } \\
\text { scale }\end{array}$ & \multicolumn{1}{|c|}{ Reaction } \\
\hline $\mathbf{1}$ & VBN $(\mathrm{Gg}) 3$ & 30 & 7 & Susceptible \\
\hline $\mathbf{2}$ & VBN $(\mathrm{Gg}) 2$ & 30 & $\mathbf{5}$ & Moderately susceptible \\
\hline $\mathbf{3}$ & MH 421 & 30 & 3 & Resistant \\
\hline $\mathbf{4}$ & IPM 410-3 & 30 & 3 & Moderately resistant \\
\hline $\mathbf{5}$ & IPM 409-4 & 30 & 7 & Susceptible \\
\hline $\mathbf{6}$ & LGG 460 & 30 & 5 & Moderately susceptible \\
\hline $\mathbf{7}$ & TM 96-2 & 30 & 3 & Moderately resistant \\
\hline $\mathbf{8}$ & Gam 5 & 30 & 7 & Susceptible \\
\hline $\mathbf{9}$ & RMG 10-28 & 30 & 1 & Resistant \\
\hline $\mathbf{1 0}$ & SML 1815 & 30 & & \\
\hline
\end{tabular}


Table.2 Chi square test for inheritance of MYMVD resistance in greengram

\begin{tabular}{|c|c|c|c|c|c|c|c|}
\hline \multirow[t]{2}{*}{ Sl. No } & \multirow[t]{2}{*}{ Generation } & \multicolumn{2}{|c|}{ Disease reaction } & \multirow{2}{*}{$\begin{array}{c}\text { Total } \\
\text { number } \\
\text { of } \\
\text { plants }\end{array}$} & \multirow{2}{*}{$\begin{array}{l}\text { Expected } \\
\text { ratio }\end{array}$} & \multirow{2}{*}{$\chi^{2}$} & \multirow{2}{*}{$\begin{array}{c}\chi^{2} \\
\text { Table } \\
\text { value } \\
(0.05)\end{array}$} \\
\hline & & Resistance & Susceptible & & & & \\
\hline 1 & $\begin{array}{l}\operatorname{VBN}(\mathrm{Gg}) 2 \mathrm{x} \\
\text { SML } 1815\end{array}$ & 131 & 10 & 141 & $15: 1$ & 0.17 & 3.841 \\
\hline 2 & $\begin{array}{l}\text { VBN(Gg) } 3 x \\
\text { SML } 1815\end{array}$ & 123 & 26 & 149 & $13: 3$ & 0.16 & 3.841 \\
\hline 3 & $\begin{array}{l}\text { VBN }(\mathrm{Gg}) 3 \mathrm{x} \\
\text { MH } 421\end{array}$ & 133 & 15 & 148 & $15: 1$ & 1.46 & 3.841 \\
\hline
\end{tabular}

Fig.1 Screening of $F_{2}$ population of VBN $(\mathrm{Gg}) 2$ x SML 1815 cross combination against MYMV disease

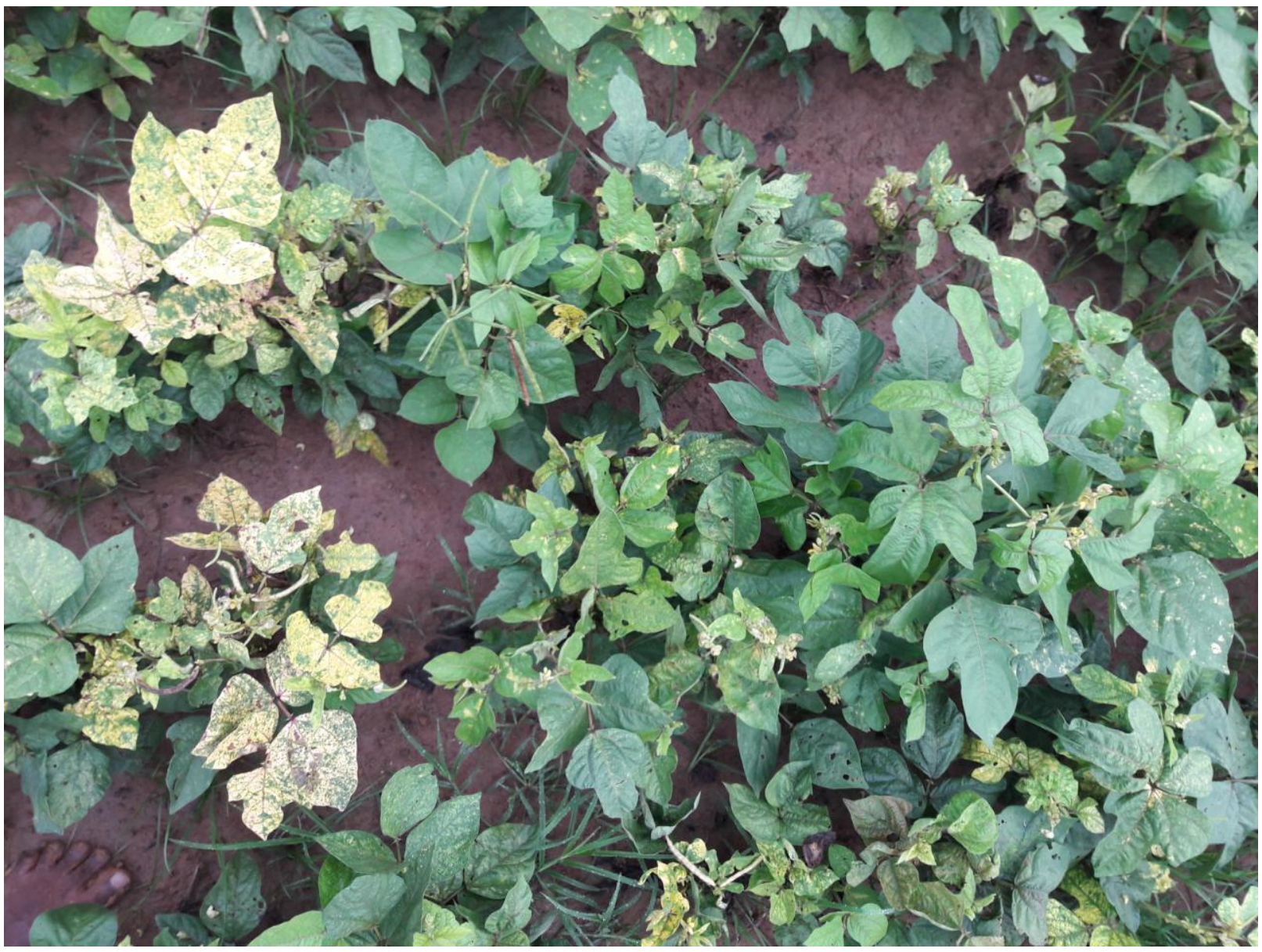

In the present study, the inheritance of MYMVD resistance in the cross combinations viz., VBN (Gg) 2 x SML 1815, VBN (Gg) 3 x $\mathrm{MH} 421$ reveals a $\mathrm{F}_{2}$ segregation ratio of 15:1
(Resistant: Susceptible), indicating the involvement of two dominant genes (Fig. 1). Whereas in VBN (Gg) 3 x SML 1815 cross combinations the $\mathrm{F}_{2}$ result revealed a ratio of 
13:3 (Resistant: Susceptible) which indicate the presence of inhibitory gene action. The present result was also in accordance with earlier report of Murugan and Nadarajan (2012), Durga Prasad et al., (2015) and Thamodharan et al., (2016).

From the above discussion it was found that, though in two crosses same female parent VBN (Gg) 3 was involved there exist two types of gene interactions viz., duplicate dominant interaction(15:1) in VBN (Gg) $3 \mathrm{x}$ SML 1815 and inhibitory dominant interaction(13:3) in $\mathrm{VBN}(\mathrm{Gg}) 3 \times \mathrm{MH} 421$. The differences in gene interaction may be attributed to the presence of modifier genes in male parents. From the above results it has been concluded that the resistance of MYMVD is under the influence of digenic dominant interaction with some modifier genes. Hence, it may appropriate to suggest the recombination breeding and delayed selection may be effective to enhance the MYMVD resistance in greengram.

\section{References}

Dahiya B.S., Singh K. and Brar J.S. 1977. Incorporation of resistance to mungbean yellow mosaic virus in blackgram (Vigna mungo (L.) Hepper). Tropical Grain Legume Bulletin, 9:28-32.

Durga Prasad, A.V.S., Murugan, E and Vanniarajan, C. 2015. Inheritance of resistance of mungbean yellow mosaic virus in Urdbean (Vigna mungo (L.) Hepper). Current Biotica., 8(4):413417.

Dwivedi, S., and Singh DP. 1985. Inheritance of resistance to yellow mosaic virus in a wide cross of blackgram (Vigna mungo L). Z Pflanzenzuecht ,95:281-284

Fauquet, C.M., D.M. Bisaro, R.W. Briddon, J.K. Brown and B.D. Harrison.2003. Virology division news: Revision of taxonomic criteria for species demarcation in the family Geminiviridae and an updated list of begomovirus species. Arch. Virol., 148: 405-421.

Gupta, S., Kumar, S., Singh, R.A. and Chandra, S. 2005. Identification of a single dominant gene for resistance to mungbean yellow mosaic virus in blackgram. SABRAO J. Breed. Genet., 37: 85-89.

Kaushal, R.P., and Singh B.M. 1988. Inheritance of disease resistance in blackgram (Vigna mungo (L.) Hepper) to Mungbean yellow mosaic virus. Indian J. Agric. Sci., 58: 123-124.

Malathi, V.G., John, P., 2008. Mungbean yellow mosaic virus. In: Encyclo. Virol. Third ed., 8 364e372.

Murugan, E., and Nadarajan, N. 2012. Genetic studies on differential expression of mungbean yellow mosaic virus resistance related to trichome density in urd bean (Vigna mungo (L.) Hepper). Indian J. Plant Genetic Resources., 25(2): 135-138.

Nariani, T.K., 1960. Yellow mosaic of mung (Phaseolus aureus). Indian Phytopathol., 13: 24-29.

Nene, Y.L., 1973. Viral diseases of some warm weather pulse crops in India. Plant Disease Reporter., 57: 463-467.

Pal, S.S., Dhaliwal HS and Bains SS. 1991. Inheritance of resistance to yellow mosaic virus in some Vigna species. Plant Breed. 106:168-171

Reddy, K.R., and Singh DP. 1995. Inheritance of resistance to mungbean yellow mosaic virus. Madras Agric. J., 88: 199-201

Shukla, G.P., Pandya, B.P and Singh, D.P. 1978. Inheritance of resistance to yellow mosaic in mungbean. Indian $\mathrm{J}$. Gene., 38: 357-360.

Singh, D.P., 1980. Inheritance of resistance to yellow mosaic virus in blackgram (Vigna mungo L.). Theor. Appl. Genet., 
52: 233-235.

Thamodhran, G., Geetha, S and Ramalingam, A. 2016. Genetic study in URD bean (Vigna Mungo (L.) Hepper) for inheritance of mungbean yellow mosaic virus resistance. International Journal of Agriculture, Environment and Biotechnology., 9(1): 33-37.

Varma, A., and Malathi G. 2003. Emerging geminivirus problems: a serious threat to crop production. Ann. Appl. Biol., 142:145-164.

Verma, R.P.S., and Singh D.P. 1986. The allelic relationship of genes giving resistance to mungbean yellow mosaic virus in blackgram. Theor. Appl. Genet., 72:737-738.

\section{How to cite this article:}

Mahalingam, A., V.K. Satya, N. Manivannan, S. Lakshmi Narayanan and Sathya, P. 2018. Inheritance of Mungbean Yellow Mosaic Virus Disease Resistance in Greengram [Vigna radiata (L.) Wilczek]. Int.J.Curr.Microbiol.App.Sci. 7(01): 880-885. doi: https://doi.org/10.20546/ijcmas.2018.701.107 